\title{
Contribution of Business and Industrial World (DUDI) in Improving Quality of Vocational High School Graduate (SMK) Expertise of Culinary in Makassar City
}

\author{
Nahriana $^{1}$, Ahmad Sonhadji K. H. ${ }^{2}$, Ahmad Dardiri ${ }^{3}$ Purnamawati $^{4}$ \\ ${ }^{1}$ Vocational Education Student, Universitas Negeri Malang, Malang, Indonesia \\ ${ }^{2}$ Departement of Mechanical Engineering Education, Universitas Negeri Malang, Malang, Indonesia \\ ${ }^{3}$ Departement of Civil Engineering, Universitas Negeri Malang, Malang, Indonesia \\ ${ }^{4}$ Departement of Electronic Engineering Education, Universitas Negeri Makassar, Makassar, Indonesia
}

\begin{abstract}
The purpose of this study is to analyse the relationship of DUDI contribution in PSG implementation and the quality of output on SMK in Culinary skill in Makassar City. The sampling technique used to determine the sample is the random sampling. The design of this study using correlational quantitative. Testing calculated by using Software Statistical Product and Service Solution (SPSS) program version 20.0 for Windows. DUDI contribution in PSG implementation on SMK Culinary Services in Makassar is still small to moderate. The quality of SMK graduates of Culinary Arts in Makassar City viewed from the competency test results is still relatively low to moderate. There is a significant and positive relationship between the contribution of DUDI in the implementation of PSG with the quality of vocational graduates of Culinary Arts in Makassar City regarding competency test results. So it can be said that the greater the contribution of DUDI in the implementation of PSG, the better the quality of vocational graduates of Culinary Services.
\end{abstract}

Keywords: Graduate Quality, Business Contribution and Industrial World, Vocational High School (SMK)

\section{Introduction}

Referring to the National Education System Law (UU) number 20 of 2003 article 3 concerning the purpose of national education states that vocational training is a secondary school that prepares students primarily to work in a particular field. Training as part of the national education system to prepare graduates to work or to continue higher levels or to work independently. The objectives and targets of vocational education in Indonesia regulated in Government Regulation (PP) 19 of 2005 Article 26 paragraph 3, namely as education to improve intelligence, knowledge, personality, noble character, and skills to live independently and follow training by the field of vocational [1]. Vocational High School (SMK) as a Vocational Education and Training institution should develop into education that can prepare students to become professional workers and able to develop a strong personality and high thinking ability. Also, the learning achievements of SMK graduates should be designed to refer to the Indonesian National Qualification Framework. To achieve this the management of SMK should orient to the quality of its graduates. Improving the quality of SMK management is essential for business and industry. Today the business world and industry expect a competent and competitive workforce. The level of relevance of school curriculum to an industry can achieve with the involvement of the stakeholders in vocational education. Therefore, to assess that the school is of high quality, that is, when the school has the power to work in the world or in other words the students of SMK graduates can apply their knowledge, skills and expertise in the world of work [2].

Understanding PSG, in this case, is a form of organisation of education and training of vocational skills that integrate systems and synchronously education programs in schools and expertise acquisition programs obtained through working directly in the world of work, directed to achieve a certain level of professional expertise. The definition implies the existence of two parties, namely vocational education institutions and business community/industrial world (DUDI) which jointly organise a training and training program [3].

The objectives of the implementation of education and training with the implementation of PSG are as follows: (1) to produce a workforce with professional expertise, i.e., the labour force in accordance with the demands of employment; (2) enhancing and strengthening Link and Match between vocational education institutions and the world of work; (3) improving the efficiency of the educational process and the need for the professional-quality workforce; (4) provide recognition and appreciation of professional experience as from the educational process [3].

In the sense of quality contains the meaning of degree (the level of excellence of a product (the work/effort) either in the form of goods or services, both tangible or intangible. Tangible quality means can be observed and viewed in the shape of the quality of an object or the form of activities and behaviour. Quality television because it has a durability (not quickly broken), the colour of the picture is bright, sounds

Volume 6 Issue 7, July 2017 www.ijsr.net 


\section{International Journal of Science and Research (IJSR) \\ ISSN (Online): 2319-7064}

Index Copernicus Value (2015): 78.96 | Impact Factor (2015): 6.391

good, and spare parts are easy to obtain, unusual behaviour, etc. While the intangible quality is a quality that can not be directly seen or observed, But can be felt and experienced, such as the atmosphere of discipline, familiarity, cleanliness and so forth [4]. The definition of quality in the concept of relative has two aspects, namely viewed from the manufacturer, then the quality is a measure based on the specified specifications and from the customer then the quality to meet customer demands [5]. Vocational schools will succeed if appropriate learning environments provided where they will work, professional training is effective if the tasks assigned to the exercise have an operational similarity with those to be employed in the future, familiarized with the behavior to be demonstrated in His work, the provision of repetitive activities so that acquired proper mastery, the trainer is quite experienced and apply the minimal ability that must be possessed by the individual [6].

\section{Research Methods}

The design of this study using correlational quantitative which is intended to find out how big the relationship between independent variables with the dependent variable. The strength of the relationship between variables can see from the size of the correlation coefficient. The variables to be tested in this research are the contribution variable of DUDI in the implementation of PSG (X) and the external quality of SMK in the field of Catering expertise (Y).

Population in this research is all vocational skill study program of Catering located in South Sulawesi Province. The Culinary Skills education program consists of the competence of Catering expertise and the ability of Patisserie's expertise. Three schools have courses of knowledge of Catering, namely: (1) SMK Negeri 4 Makassar; (2) SMK Negeri 6 Makassar; And (3) SMK Negeri 8 Makassar.

The sampling technique used to determine the sample is random sampling because the analysis has the assumption of random sampling or probability sampling. While to determine the number of samples used random number table with the error rate $\alpha=5 \%$

The technique used to test the validity of the instrument is to correlate between the item scores with the total score of the question. Validity testing is calculated using the Software Statistical Product and Service Solution (SPSS) version 20.0 for Windows. The test criteria are as follows: (a) If $r$ arithmetic $\geq \mathrm{r}$ table, then the instrument or question items correlate significantly to the total score, then declared valid; And (b) If $r$ arithmetic $<r$ table, then the tool or question things are not significantly correlated to the total score, then it is declared invalid.

After testing the validity, then the reliability test is done to determine the extent to which an instrument can be trusted. Testing done by Cronbach Alpha statistical analysis using SPSS version 20.0 for Windows. Tools can be said reliably if the value of $r$ arithmetic $>r$ table at a significance level of 0.05 .

\section{Result and Discussion}

\subsection{Descriptive Analysis}

Research data obtained from the documents and questionnaires that have been distributed to the respondents as much as 50 respondents from three SMKs of Culinary services as Makassar city. As for the data analysis used descriptive statistics and inferential statistics. Descriptive statistics are used to describe the data of the variables studied and the inferential statistics used for the test requirements analysis and hypothesis testing.

\section{The Contribution of DUDI in Implementation of PSG}

The DUDI contribution instrument in PSG implementation consists of 30 items. From the processing of data collection result, the frequency distribution of DUDI contribution in the implementation of PSG as a whole presented in Table 1 below.

Table 1: Distribution of Frequency of DUDI Contribution in the Implementation of PSG

\begin{tabular}{|c|c|c|}
\hline Contribution & Frequency & Percentage \\
\hline Very High & 8 & 16 \\
\hline High & 9 & 18 \\
\hline Medium & 20 & 40 \\
\hline Low & 12 & 24 \\
\hline Very Low & 1 & 2 \\
\hline Total & 50 & 100 \\
\hline
\end{tabular}

Based on Table 1 above, it known that as many as 8 respondents or $16 \%$ considered that the contribution of DUDI in the implementation of PSG is very high category, 9 respondents or $18 \%$ felt that the input of DUDI in the implementation of PSG included top category, 20 respondents or $40 \%$ DUDI's contribution in the implementation of PSG is moderate, while 12 respondents or $24 \%$ consider that the input of DUDI in PSG implementation is small, and 1 respondent or $2 \%$ think that DUDI contribution in PSG implementation is deficient category.

\section{Quality Graduates of Vocational School of a Culinary}

The quality of SMK graduates obtained from the documentation data of competency test results of the field of Culinary Services conducted in schools at the end of the study period. From the processing of data collection result, the distribution of quality frequency of vocational graduates of Catering Services as a whole presented in Table 2 below.

Table 2: Distribution of Quality Frequency of Vocational Graduate of Catering Service Division

\begin{tabular}{|l|c|c|}
\hline \multicolumn{1}{|c|}{ Contribution } & Frequency & Percentage \\
\hline Very High & 8 & 16 \\
\hline High & 6 & 12 \\
\hline Medium & 23 & 46 \\
\hline Low & 11 & 22 \\
\hline Very Low & 2 & 4 \\
\hline \multicolumn{1}{|c|}{ Total } & 50 & 100 \\
\hline
\end{tabular}

Based on Table 2, it known that as many as 8 respondents or $16 \%$ have the quality of graduates in terms of competency 


\section{International Journal of Science and Research (IJSR) \\ ISSN (Online): 2319-7064}

Index Copernicus Value (2015): 78.96 | Impact Factor (2015): 6.391

test results are very high category, 6 respondents or $12 \%$ have the quality of graduates in terms of competency test results are categorized high, 23 respondents or equal to $46 \%$ Graduates viewed from the results of competency tests are moderate category, 11 respondents or $22 \%$ have the quality of graduates in terms of competency test results are low categorized, and 2 respondents or $4 \%$ have the quality of graduates in terms of competency test results are very small category.

\subsection{Normality test}

The proof that residual values are standard spread is one indication that the multiple linear regression equations obtained is good enough and it can conclude that the probability of getting a residual value around zero is greater than the probability value which is far from zero. Proof of normality of residual value done by using KolmogorovSmirnov test. Normality test with Kolmogorov-Smirnov is said to be normal if the p-value is greater than 0.05 [7]. Normality test results presented in Table 3 below.

Table 3: Test Result Normality with Kolmogorov-Smirnov

\begin{tabular}{|c|c|c|c|c|c|c|}
\hline & \multicolumn{3}{|c|}{ Kolmogorov-Smirnov $^{\mathrm{a}}$} & \multicolumn{3}{c|}{ Shapiro-Wilk } \\
\hline & Statistic & $\mathrm{df}$ & Sig. & Statistic & $\mathrm{df}$ & Sig. \\
\hline $\mathrm{x}$ & 0.096 & 50 & $.200^{*}$ & 0.959 & 50 & 0.082 \\
\hline $\mathrm{y}$ & 0.123 & 50 & 0.068 & 0.961 & 50 & 0.097 \\
\hline
\end{tabular}

Based on data processing with SPSS as in Table 3 obtained value of p-value or probability significance of 0.200 and 0.068 greater than 0.05 so it concluded that the data is categorised normal distribution.

\subsection{Hypothesis Testing Analysis}

Testing the hypothesis to determine whether or not the relationship between the contribution of DUDI in the implementation of PSG with the quality of graduate SMK in Culinary Services from the results of competency test. For hypothesis testing the researcher use 5\% significance level, then price obtained from statistical calculation consulted with table calculation (compare r-count with r-table). If the known $\mathrm{r}$-count is greater than the rtabel then the correlation coefficient is said to be significant and vice versa.

To test the hypothesis, the analysis technique used is Product Moment correlation technique calculated using SPSS version 20 For Windows. The result of Product Moment correlation calculation is as follows in Table 4.

Table 4: Hypothesis Testing Results

\begin{tabular}{|c|c|c|c|c|}
\hline & $\mathrm{R}$ & R Square & Adjusted R Square & $\begin{array}{c}\text { Std. Error of the } \\
\text { Estimate }\end{array}$ \\
\hline 1 & $.393^{\mathrm{a}}$ & .154 & .137 & 9.92236 \\
\hline
\end{tabular}

From the results of data analysis above shows Product Moment correlation between DUDI contribution in the implementation of PSG with the quality of vocational high school graduates in the field of Catering Services from the results of competency test of 0.393 (r-count). The coefficient of determination $\left(\mathrm{r}^{2}\right)$ is 0.154 . Then the results are consulted with the r-table at a significance level of $5 \%$ to test the standard of significance. The correlation coefficient on $\mathrm{r}$ table with the significance level of $5 \%$ and $\mathrm{N}=50$ is 0.279 . This result shows that $\mathrm{r}$-count is bigger than r-table. Thus there is a positive and significant relationship between the contribution of DUDI in the implementation of PSG with the quality of vocational graduates of Culinary Services regarding competency test results. Thus, the higher the input of DUDI in the implementation of PSG, the higher the quality of vocational graduates of Culinary Services from the results of competency test.

\subsection{Discussion}

The result of the analysis shows that there is a significant and positive correlation between the contribution of DUDI in PSG implementation with the quality of SMK Graduate of Culinary Services field in Makassar City regarding competency test result. From the analysis results can be said that the greater the contribution of DUDI in the implementation of PSG, the better the quality of vocational graduates of the field of Culinary Services.

Business world/industry has a significant role in successful implementation of PSG. Industrial involvement in PSG in creating SMK partnerships with DU / DI includes providing a place of practice for students, provision of funds for the implementation of PSG, designing educational programs and program implementation up to the evaluation of student learning outcomes in vocational education.

Prakerin is one form of policy implementation of the Ministry of Education and Culture in the concept of "link and match" through Dual System Education (PSG) between education and work world. Industrial Work Practices is a form of teaching that involves students directly working in the World Business / Industrial World. Industrial Work Practice aims to learners have competencies that match the expectations and demands of the World Business / Industrial World, as well as to obtain work experience as one of the things to improve professional skills.

The purpose of the implementation of Industrial Work Practices is to improve the quality of Vocational High School graduates (knowledge), skills, and work ethics by the demands of employment so that SMK graduates ready to enter the labour market. The type of expertise and number of graduates produced by SMK has not been all in line with labour market demand.

The school has limitations in the financing and provision of learning environments, while the industry has limited educational resources to form the required workforce. Therefore, to get ready-made vocational graduates, both parties should make efforts, or at least the involvement of industry to participate in formulating training programs. The role of Industry should be shown clearly in the form of cooperation and financial support programs so that the quality of graduates in SMK Catering Services is right, by the needs of DUDI so that graduates can be absorbed in the work field. School and industry collaboration must build on the willingness and mutual need. Working and modern world 
parties should be aware that the industry will not get the ready-made workers they need on the desired terms, without building a joint education program.

\section{Conclusion}

The contribution of DUDI in the implementation of PSG in Catering Services SMK in Makassar is still small to moderate, i.e., $40 \%$ of respondents stated average, and $24 \%$ of respondents said flatly. The quality of graduates of a vocational sector of Culinary Services in Makassar City regarding competency test is still relatively small to moderate, that is $46 \%$ classified as moderate, and $22 \%$ is low. There is a significant and positive relationship between the contribution of DUDI in the implementation of PSG with the quality of vocational graduates of Culinary Arts in Makassar City regarding competency test results. So it can be said that the greater the contribution of DUDI in the implementation of PSG, the better the quality of vocational graduates of Culinary Services.

\section{References}

[1] Undang-Undang Republik Indonesia, "Nomor 20 Tahun 2003," Tentang Sist. Pendidik. Nas., no. 1, pp. 1-26, 2003.

[2] C. R. Finch and J. R. Crunkilton, Curriculum Development in Vocational and Technical Education: Planning, Content, and Implementation. Boston: Allyn and Bacon, 1999.

[3] Direktorat Pendidikan Menengah Kejuruan, "Konsep Pendidikan Sistem Ganda pada SMK di Indonesia." Depdikbud, Jakarta, Indonesia, 1996.

[4] Suryosubroto, B., Manajemen Pendidikan di Sekolah. Rineka Cipta, 2004.

[5] Edward, Sallis., Total Quality Management in Education. London: Kogan Page, 1993.

[6] Prosser, Charles Allen. and Quigley, Thomas Henry., Vocational Education: In a Democracy. Chicago: American Technical Society, 1949.

[7] Santoso, Singgih., SPSS 22 from Essential to Expert Skills. Jakarta: PT. Elex Media Komputindo, 2014. 